\title{
A previdência privada como instrumento de planejamento sucessório
}

\section{Private pension as an instrument of succession planning}

\author{
Mairan Gonçalves Maia Junior*
}

\section{Resumo}

\begin{abstract}
O presente artigo analisa a aptidão da previdência privada como instrumento de planejamento sucessório. A partir da natureza jurídica da previdência privada, aborda sua compatibilidade como meio de planejamento sucessório, suas vantagens e os problemas decorrentes de seu uso com esse escopo, em particular o eventual descumprimento da legítima e a fraude à disposição de regra de sucessão. Apresenta as posições divergentes do STJ e de Tribunais de Apelação sobre a questão.
\end{abstract}

Palavras-chave: Previdência privada. Planejamento sucessório. Sucessão. Legítima.

\section{Abstract}

This article analyzes the suitability of private pension funds as an instrument of succession planning. From the legal nature of the private pension plan, it addresses its compatibility as a means of succession planning, its advantages and the problems arising from its use with this scope, in particular the eventual noncompliance with the mandatory part of the heritance and the possibility of fraud. It presents the divergent positions of the STJ and Appeal Courts on the issue.

Keywords: Private pension funds. Succession planning. Succession. Heritance.

\section{Introdução}

A incerteza quanto ao futuro e à suficiência da previdência comum para suportar os gastos com a aposentadoria tem estimulado os brasileiros a buscar a previdência privada complementar, oferecida por grandes instituições securitárias e financeiras. Na verdade, a população tem sido, de certo modo, direcionada às instituições de previdência privada em virtude das constantes reformas sofridas pela previdência em geral, tanto a privada como a pública, as quais apresentam como ponto comum a crescente deterioração da situação do aposentado. Vive-se, atualmente, momento de mais uma reforma, com as incertezas de seus resultados e a insegurança quanto à existência de renda no futuro que possa suportar os custos da velhice.

A mudança de perfil da família brasileira tem desafiado a efetividade das regras da sucessão legítima, que foram moldadas para o standard familiar vigente quando do Código Civil de 1916. O descompasso entre as regras sucessórias e as realidades familiares tem gerado o interessante fenômeno de despertar nas pessoas a preocupação com a forma pela qual a transmissão patrimonial em função do evento morte se sucederá.

Como consequência desse despertar, constata-se a constante e crescente preocupação em planejar a sucessão. O planejamento abrange, basicamente, quatro fases: i) a definição dos herdeiros e legatários; ii) a delimitação do patrimônio a transmitir; iii) a fixação dos objetivos pretendidos; iv) a escolha dos instrumentos jurídicos aptos a viabilizar a consecução dos fins fixados pelo planejamento.

Por sua própria natureza, o testamento é o instrumento jurídico natural ao planejamento sucessório. Entretanto tem-se verificado, com relativa frequência, a criação de pessoas jurídicas, denominadas de holdings patrimoniais, com o objetivo de concentrar o patrimônio do titular e possibilitar sua transferência

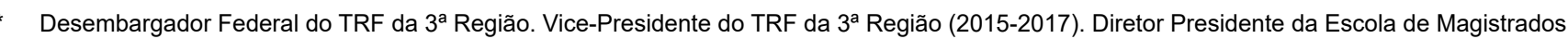
do TRF da $3^{\text {a }}$ Região (2012-2014). Conselheiro do CNJ (2007-2009). Mestre e Doutor em Direito Civil pela Pontifícia Universidade Católica de São Paulo. Livre-Docente em Direito Civil pela PUC/SP. Estágio de Pós-doutorado realizado no Instituto Max Planct de Direito Internacional Privado e Comparado, no período de set-dez 2018, em Hamburgo, Alemanha. Professor Assistente Mestre da Pontifícia Universidade Católica de São Paulo dos cursos de Gradução e Pós-Graduação stricto sensu. São Paulo - SP - Brasil. E-mail: mairanjr@yahoo.com.br.
} 
aos herdeiros por meio da transmissão de quotas sociais, nos termos do estatuto social da pessoa jurídica constituída.

Pretende-se, também, desse modo, evitar a incidência da tributação sobre o patrimônio transmitido mortis causa. A criação de pessoas jurídicas com essa finalidade não é, todavia, desprovida de riscos.

Outros instrumentos jurídicos presentes no ordenamento jurídico brasileiro vêm sendo utilizados, também, com o escopo de planejar a sucessão mortis causa, como é o caso dos contratos de doação e da instituição de previdência privada. Nesses casos, há a utilização de instrumento jurídico com finalidade que não lhe é, a priori, própria.

Interessa ao presente estudo investigar a aptidão ou não do uso de previdência privada como instrumento de planejamento sucessório, sua adequação a essa finalidade, as vantagens e os problemas decorrentes de seu uso com esse objetivo, e, em particular, investigar se há descaracterização da previdência privada como instituição de natureza securitária quando utilizado como instrumento de planejamento sucessório e a posição dos tribunais pátrios a respeito.

\section{Aspectos gerais das instituições de previdência privada}

As previdências privadas são instituições antigas. Na vigência do Código Civil de 1916, eram instituídas com base em seu art. 1.466, sob a forma de "sociedades de seguro mútuo", "sociedades de montepio" e denominadas, simplesmente, de Montepio. ${ }^{1}$

Segundo Rodrigo José de Kühl e Carvalho (2004, p. 123), com a edição da Lei n. ${ }^{\circ} 6.435 / 1977$ "passaram a ser denominadas de 'entidades abertas de previdência privada sem fins lucrativos' sem que, com isso, houvesse-Ihes sido alterada a natureza jurídica". Por essa razão, assevera que "continuam, pois, a ser 'seguradoras', organizadas sob a forma de 'sociedades civis especiais' (ou 'associações especiais' de acordo com a tese que preferir o intérprete), mesmo depois da Lei n. ${ }^{\circ} 6.435 / 1977$ e da LC n. ${ }^{\circ} 109 / 01 . "$

Muitos foram contribuintes da Capemi, da Aplub e do Montepio militar. Os contribuintes das referidas previdências, no entanto, não puderam resgatar suas reservas, formadas ao longo dos anos com as contribuições efetuadas, nem receber as prestações contratadas, em função da "quebra" das referidas instituições.

Esse é o primeiro risco que envolve a previdência privada: a conservação do estado de solvência da instituição junto à qual é contratada. Os contratos de previdência privada são, pela própria natureza, contratos de longa duração, pois almejam a formação de reserva financeira suficiente para possibilitar o resgate em parcelas mensais aptas a suportar o custo de vida ao se aposentar. Em nosso país, no entanto, poucas são as instituições securitárias e financeiras que ultrapassam cinquenta anos.

A crise da previdência pública e a oferta de novos e variados produtos pelas instituições financeiras, bem como as vantagens que propiciam, estimulam sua procura, a despeito de seus riscos genéricos, ${ }^{2}$ como aponta Gonçalves (2006, p. 108).

O regime de previdência privada de caráter complementar tem sua matriz constitucional prevista no art. 202 da CF, cuja regulamentação foi delegada à Lei Complementar.

Em atendimento à disposição constitucional foi editada a Lei Complementar n. ${ }^{\circ} 109$, de 29.05.2001, disciplinando os planos de previdência privada, os quais são fiscalizados pela Susep (Superintendência de Seguros Privados). Consoante preconizado em seu art.2..$^{\circ}$ o "regime de previdência complementar é operado por entidades de previdência complementar que têm por objetivo principal instituir e executar planos de benefícios de caráter previdenciário, na forma desta Lei Complementar."

A Lei Complementar n. ${ }^{\circ}$ 109/01 é a viga mestra normativa do regime jurídico dos fundos de previdência complementar.

Eram regidas pela Lei $n .^{\circ} 6.435 / 77$ e pelos Decretos n. ${ }^{\circ} 81.302 / 78$ e 81.240/78.

Antônio Batista Gonçalves (2006, p. 108) questiona, de modo crítico, a utilização do PGBL e do VGBL como investimento financeiro. 
De acordo com o art. $4 .^{\circ}$ da referida lei, as entidades de previdência complementar são classificadas em fechadas e abertas. Ao planejamento sucessório interessa, notadamente, os planos de previdência privada abertos.

As entidades de previdência complementar abertas são regulamentadas, no que couber, pela legislação aplicável às sociedades seguradoras, consoante previsto no art. 73 da LC n. ${ }^{0}$ 109/10. Por esse motivo, Ihe são aplicáveis as Resoluções do Sistema Nacional de Seguros (CNSP e SUSEP), em particular as resoluções n. ${ }^{\circ}$ 117/2004; 139/2005 e 140/2005.

A Resolução n. ${ }^{\circ}$ 117/2004 regulamenta os seguros de pessoas e disciplina a possibilidade de instituição do regime de capitalização (artigos $8 .^{\circ}, 48$ e 49), com o resgate facultativo (art. ${ }^{\circ} 41$ ). A Resolução n. ${ }^{\circ}$ 139/05 dispõe sobre a cobertura de sobrevivência oferecida pelos planos de previdência complementar, sendo o PGBL expressamente previsto em seu art. $7 .^{\circ}$, inciso I. Por seu turno, a Resolução n. ${ }^{\circ}$ 140/05 trata da cobertura por sobrevivência nos seguros de pessoas, disciplinando o VGBL em seu art. $7 .^{\circ}$, inciso I.

Os planos de previdência privada instituídos por entidades abertas podem ser individuais ou coletivos, ex vi do art. 26, I e II, da Lei Complementar n. ${ }^{\circ}$ 109/01. Os planos coletivos são vinculados, direta ou indiretamente, a uma pessoa jurídica contratante, e têm por objetivo garantir benefícios previdenciários às pessoas físicas a ela ligadas. Os individuais são acessíveis a qualquer pessoa física.

Os planos de previdência privada individuais abertos, assim considerados os passíveis de serem feitos por qualquer interessado, podem ser realizados sob duas modalidades: VGBL (Vida Gerador de Benefícios Livres) e PGBL (Plano Gerador de Benefícios Livres).

Ambos são planos por sobrevivência - de seguro de pessoas e de previdência complementar aberta - que, depois de período de captação de recursos (período de diferimento), proporcionam aos investidores (segurados e participantes) a obtenção de renda mensal. A renda pode ser percebida de modo parcelado, em caráter vitalício ou por prazo determinado, e ainda pode o valor integral acumulado ser resgatado em um pagamento único.

O PGBL, por força do disposto no art. 69 da LC n. ${ }^{\circ}$ 109/01, permite a dedução, na base de cálculo do imposto de renda da pessoa física, do valor contribuído anualmente até o montante de $12 \%$ (doze por cento) da renda bruta anual do investidor. Por esse motivo, pode ser também utilizado para fins de planejamento tributário, em razão dos benefícios auferidos.

Ademais, pode vir a ser bom investimento financeiro, a depender das condições pactuadas com a instituição financeira, principalmente nas aplicações de longo prazo, em função da redução progressiva da alíquota do imposto de renda e das taxas de administração. Em virtude desse aspecto, tem sido também considerado como investimento financeiro, sem que perca sua natureza securitária. Nos prazos superiores, há dez anos, incide a alíquota de 10\%, a menor possível. A Lei n. ${ }^{\circ} 11.053$, de 29.12.2004, dispõe sobre a tributação dos planos de benefícios de caráter previdenciário e dá outras providências.

\section{A natureza jurídica das reservas de previdência privada}

O VGBL é classificado como seguro de pessoa. Por seu turno, o PGBL constitui plano de previdência complementar. Ambos, portanto, possuem natureza securitária, de acordo com a feição que a Lei Complementar n. ${ }^{0}$ 109/01 Ihes atribui. Em virtude da natureza securitária que apresentam, se lhes aplica o art. 794 CC02, o qual prescreve que, no seguro de vida ou de acidentes pessoais para o caso de morte, o capital estipulado não está sujeito às dívidas do segurado, nem se considera herança para todos os efeitos de direito.

A Lei Complementar n. ${ }^{0}$ 109/01, em diversos de seus dispositivos, reforça a natureza securitária dos referidos fundos. Assim, exemplificativamente, prevê: i) a possibilidade das entidades de previdência complementar contratarem operações de resseguro - art. 11; ii) a aplicação da legislação e regulamentação da profissão de corretor de seguros aos corretores de planos de benefício - art. 30, parágrafo único; iii) a possibilidade de as seguradoras autorizadas a operar exclusivamente no ramo vida a operar os planos de 
benefícios - art. 36, parágrafo único; iv) a aplicação da legislação das sociedades seguradoras às entidades abertas de previdência privada - art. 73.

É importante fixar a natureza jurídica dos planos de previdência privada abertos, por refletir, diretamente, na transmissibilidade ou não das reservas acumuladas aos seus herdeiros quando da morte do titular. Como as reservas constituídas nos planos VGBL e PGBL possuem natureza e finalidade securitárias, não são transmissíveis, por sucessão mortis causa, aos herdeiros legítimos ou testamentários do falecido, quando indicados beneficiários no plano de previdência privada.

Ausente a indicação de beneficiários, a reserva constituída, como direito de crédito, será incorporada ao patrimônio transmissível do falecido e, nesse caso, transferida a seus herdeiros legítimos ou testamentários.

Desse modo, a metade do capital será destinada ao cônjuge, a depender do regime de bens, e a outra parte aos herdeiros legítimos, observada a ordem legal de sucessão, conforme prevê o art. 792 CC02. Ausentes os beneficiários legais, o parágrafo único do art. 792 CC02 estabelece que o capital irá "aos que provarem que a morte do segurado os privou dos meios necessários à subsistência" .

Como regra geral, portanto, os valores depositados nos fundos de previdência privada não são transferíveis aos sucessores do titular em virtude de sua morte, mas são inteiramente direcionados aos beneficiários indicados nas apólices contratadas.

\section{As vantagens de sua utilização no planejamento sucessório}

As apólices de previdência privada têm por finalidade básica o complemento da renda quando da aposentadoria de seu titular. No entanto, além de atenderem a essa finalidade, os fundos de previdência privada constituem importante instrumento de planejamento financeiro, tributário e sucessório.

No presente momento, interessa analisar sua utilização como instrumento do planejamento sucessório, exclusivamente.

Como as reservas constituídas não compõem o patrimônio transmissível aos herdeiros, seus valores não se sujeitam a inventário, podendo ser liberados aos beneficiários em curto prazo, o qual pode variar de 48 horas a 30 dias, a depender da instituição financeira. Não se tem, dessa forma, custo com advogados, com processos judiciais ou procedimentos extrajudiciais.

Assim, por não integrarem o montante da herança a partilhar, não compõem a base de cálculo do ITCMD (imposto de transmissão causa mortis e doação), cuja alíquota pode variar, a depender do estado, de $2 \%$ a $8 \%$ (dois a oito por cento). A maior parte dos estados brasileiros adota tabela progressiva de incidência de ITCMD. Em 2015, em virtude da crise fiscal, vários estados a majoraram, e o governo federal apresentou Proposta de Emenda à Constituição (PEC n. ${ }^{\circ}$ 95/2015) com a finalidade de outorgar competência à União Federal para instituir adicional sobre o imposto estadual.

As reservas dos fundos de previdência privada não sofrem a incidência do ITCMD, eliminando o custo de tributação. Preserva-se, desse modo, o montante acumulado, com maior proveito para os beneficiários.

Outra grande vantagem dos planos de previdência privada é a prévia indicação dos beneficiários, os quais podem ser pessoas vinculadas à família do segurado ou não. Entende-se por beneficiários as pessoas físicas indicadas livremente pelo participante do plano para receber os valores de benefício ou resgate, quando de seu falecimento, em conformidade com a estrutura do plano.

Não somente a definição dos beneficiários é feita pelo próprio titular, que pode indicar livremente quantas pessoas físicas desejar, como também o estabelecimento do percentual a ser destinado a cada uma delas. A indicação é feita no momento da realização do plano de previdência, mas pode ser modificada pelo titular, a qualquer tempo, perante a instituição de previdência privada, como também admite a inclusão de novos beneficiários, não constantes no momento de sua realização.

O art. 793 CC02 permite a instituição do companheiro como beneficiário se, ao tempo do contrato, o segurado já era separado judicialmente ou já se encontrava separado de fato. A contrario sensu, é vedada a indicação de concubina ou concubino. Incide, também, a restrição prevista no art. 1.801 do CC02. 
Como aduz Solledero, "a razão é, sem dúvida, que o seguro de vida é suspeito de ter sido subscrito tendo em vista a mantença de relações adúlteras". (SOLLEDERO, 2003, p. 118).

A flexibilidade na indicação dos beneficiários, a possibilidade de sua fácil modificação, bem como a definição prévia do percentual do valor depositado que será destinado a cada um deles, constituem importantes vantagens desse instrumento para fins de planejamento sucessório.

Como os valores depositados nos fundos não integram, tecnicamente, a herança a transmitir, os beneficiários não são considerados herdeiros. Não precisa, a priori, portanto, ser observada a legítima reservada aos herdeiros legítimos necessários, por força do art. 1.846 CC02.

Do mesmo modo, não se sujeita o titular do investimento a observar a igualdade dos quinhões entre os herdeiros de mesma classe, ou seja, pode destinar percentuais distintos para cada pessoa indicada como beneficiária.

Por exemplo, na hipótese do titular apontar como beneficiários quatro pessoas, que, de acordo com as regras da sucessão legítima, seriam chamados conjuntamente a suceder, poderá destinar a uma 10\% (dez por cento); a outra, 35\% (trinta e cinco por cento); à terceira, 30\% (trinta e cinco por cento); e à quarta, $25 \%$.

Caso os beneficiários fossem considerados herdeiros legítimos, chamados a suceder na mesma classe de sucessores e de mesmo grau, quer fossem ascendentes, descendentes ou colaterais, deveria ser destinado a cada um o mesmo montante, ou seja, $25 \%$ (vinte e cinco por cento) do valor depositado, pois, de acordo com as regras da sucessão legítima, aos herdeiros de mesma classe convocados à sucessão são destinados quinhões iguais. ${ }^{3}$

A celeridade, a economia e a adequabilidade à vontade do titular do patrimônio constituem vantagens relevantes da utilização dos fundos de previdência privada. Essas características tornam atrativa sua utilização, também, como instrumento de planejamento sucessório.

\section{A posição do STJ}

No julgamento do REsp n. ${ }^{\circ}$ 1.477.937/MG, de relatoria do e. min. Villas Bôas Cueva, o STJ decidiu pela incomunicabilidade dos valores depositados em fundo de previdência privada fechada, e o excluiu da partilha dos bens do casal, por incidir o disposto no art. 1.659, VII, do CC02. No voto proferido foi, ainda, destacada a importância da reserva constituída para o equilíbrio financeiro e atuarial do plano de previdência.

$O$ voto ressaltou, também, a desnecessidade de ser considerado o regime de bens do casamento do participante do plano, por não se tratar de "verba tipicamente trabalhista, mas, sim, de pensão cuja natureza é distinta."

$\mathrm{Na}$ verdade, a natureza securitária das reservas constituídas em planos de seguro de vida, e, consequentemente, sua intransmissibilidade, já tinha sido anteriormente fixada pelo STJ em acórdão da lavra do min. Luís Felipe Salomão. Ao apresentar seu voto, destacou o relator:

2. No caso, a principal questão controvertida consiste em saber se, em contrato de seguro de vida, cuja apólice designa beneficiário específico, tem o Espólio da segurada legitimidade para ajuizar ação de cobrança da indenização securitária.

2.1. De fato, conforme observado no voto vencido do Relator originário, à luz do art. 794 do Código Civil/2002, no seguro de vida ou de acidentes pessoais para o caso de morte, o capital estipulado não está sujeito às dívidas do segurado, nem se considera herança para todos os efeitos de direito. A razão de ser é singela: evidentemente, no seguro de vida, o beneficiário - titular da indenização securitária - é o terceiro designado pelo falecido, por isso é descabido que tal direito componha o acervo hereditário.

Ressalvem-se as disposições dos art. ${ }^{0} 1.832$, parte final, e 1.837, parte final, aplicável na sucessão do cônjuge concorrendo com descendentes e ascendentes, respectivamente.

4 REsp n. ${ }^{0}$ 1.477.937/MG, 3. ${ }^{\text {a }}$ Turma, v. u., j. em 27.04.17. 
Isso porque, nessas hipóteses, ocorrido o sinistro, o capital segurado pertence a um beneficiário que é necessariamente um terceiro. Ou seja, segurado e beneficiário, nesses casos, obviamente não podem ser uma só pessoa. E, sendo assim, tratando-se de valor pertencente ao beneficiário, não se sujeita às dívidas do segurado nem se considera herança, pois, se instituído, pelo contrato, em favor de um herdeiro necessário, por exemplo, não está submetido à colação. (PELUSO, Cezar (coord.). Código civil comentado. 6. ed. Barueri: Manole, 2012, p. 817). ${ }^{5}$

Em decisão monocrática proferida em 01.02.17, da lavra do min. Antônio Carlos Ferreira, nos autos de processo em que se discutia a ocorrência ou não de sonegação de bens da herança, esse entendimento foi ratificado e decidiu-se, expressamente, não integrar o plano de previdência privada, na modalidade VGBL, a herança, em virtude do disposto no art. 1.794 CC02. Destaca-se da decisão do e. relator:

A apelada, nomeada inventariante no inventário de bens deixados por [...] (fls. 22), não ocultou os planos de previdência privada, indicados pela apelante em sua petição inicial, quais sejam (i) Plano Flex VGBL Middle RF n 0722.0000450-4; (ii) Plano Flex VGBLPlus RF n0720.0059921-6; e (iii) Plano Flex VGBL Plus Investors RFn 0737.0009974-7 e nº 0737.0009075-4 (fls. 11). Há notícia expressa da existência dos mencionados planos nas Primeiras Declarações (fls. 51/60), conforme se infere da leitura do item 'BENS ISENTOS DE TRIBUTAÇÃO' (fls. 59). Mas não é só. Consta dos autos do inventário cópia dos respectivos contratos (fls.69/75). Com efeito, não houve atuação intencional da apelada em desviar bens ou de deixar de trazê-los ao inventário, como pretende a apelante. Ademais, é de rigor consignar que os planos de previdência privada não integram o acervo hereditário. E tudo porque, 'tratando-se de valor pertencente ao beneficiário, não se sujeita às dívidas do segurado nem se considera herança, pois, se instituído, pelo contrato, em favor de um herdeiro necessário, por exemplo, não está submetido à colação' (in 'Código Civil Comentado', Coordenador Ministro Cezar Peluso comentário de Cláudio Luiz Bueno de Godoy ao supracitado artigo 794 do CC, Editora Manole).

\section{$[\ldots]$}

Assim, considerando que o arrolamento dos contratos de previdência privada nos autos do inventário demonstrou a lisura da atuação da apelada, merece subsistir a r. sentença.

$[\ldots]$

Ante o exposto, NEGO PROVIMENTO ao agravo. ${ }^{6}$ (grifou-se).

A rigor, seria, até mesmo, desnecessária a inclusão dos referidos valores na declaração de bens do inventário, uma vez que não integravam a herança a partilhar.

Recentemente, em decisão datada de 27.06.2017, em feito no qual se objetivava a inclusão na herança dos valores provindos de previdência complementar, a min. Maria Isabel Gallotti reforçou a intransmissibilidade dos valores constituídos em reserva a título de VGBL ou PGBL, nos seguintes termos:

Como já salientado, verifico que o Tribunal de origem, ao analisar o contrato de VGBL firmado pelo de cujus, as circunstâncias fáticas e as provas produzidas nos autos, entendeu que o plano firmado pelo de cujus possui natureza jurídica de contrato de seguro de vida, de modo que não pode ser enquadrada como herança e, portanto, não pode ser objeto de penhora e bloqueio nos autos do inventário para fins de partilha. Não é outro o entendimento deste Superior Tribunal de Justiça, conforme se depreende da leitura dos seguintes precedentes:

$[\ldots]$

No mesmo sentido é a conceituação prevista no sítio eletrônico da Superintendência de Seguros Privados - SUSEP, que, alinhada à disposição contida no artigo 794, do Código Civil, não deixam dúvidas que o VGBL não deverá integrar o acervo hereditário do falecido e não responderá por suas dívidas: VGBL (Vida Gerador de Benefícios Livres) e PGBL (Plano Gerador de Benefícios Livres) são planos por sobrevivência (de seguro de pessoas e de previdência complementar aberta, respectivamente) que, após um período de acumulação de recursos (período de diferimento), proporcionam aos investidores (segurados e participantes) uma renda mensal - que poderá ser vitalícia ou por período

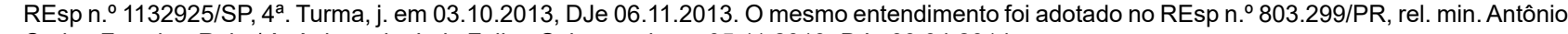
Carlos Ferreira, Rel p/ Acórdão min. Luis Felipe Salomão, j. em 05.11.2013, DJe 03.04.2014.

$6 \quad$ A REsp n. ${ }^{\circ}$ 1.041.978-SP (2017/0007008-6), decisão datada de $1^{\circ}$ de fevereiro de 2017. 
determinado - ou um pagamento único. O primeiro (VGBL) é classificado como seguro de pessoa, enquanto o segundo (PGBL) é um plano de previdência complementar. Art. 794. No seguro de vida ou de acidentes pessoais para o caso de morte, o capital estipulado não está sujeito às dívidas do segurado, nem se considera herança para todos os efeitos de direito. Com efeito, verifico que o Tribunal de origem decidiu em consonância com a jurisprudência já consolidada desta Corte, o que igualmente atrai o óbice previsto na Súmula ${ }^{\circ}$ 83/STJ, aplicável aos recursos interpostos com base em ambas as alíneas (AgInt no AREsp 720.037/SC, Rel. Ministra MARIA ISABEL GALLOTTI, QUARTA TURMA, julgado em 3/5/2016, DJe 11/5/2016). ${ }^{7}$

Atualmente, essa é a posição definida pelo C. STJ, que reconhece a natureza securitária dos fundos de previdência privada (VGBL e PGBL), excluindo-os da herança a ser partilhada entre os herdeiros legítimos ou testamentários, ressalvada a hipótese de ausência de indicação de beneficiários.

\title{
6 Problemas decorrentes de sua utilização como instrumento de planejamento sucessório
}

Deve fazer parte do planejamento sucessório o estudo das possíveis dificuldades que sua implementação poderá enfrentar. Por esse motivo, são enumeradas algumas questões que podem ser levantadas, a título exemplificativo, em relação aos planos de previdência privada:

\subsection{Questionamento quanto à natureza jurídica}

Apesar da consolidada posição do STJ quanto à natureza jurídica das reservas constituídas a título de previdência privada complementar, e sua exclusão da herança a ser partilhada, existem posições em Tribunais de Apelação estaduais - Tribunais de Justiça - que não observam a diretriz traçada pelo STJ.

Ilustrativamente, cite-se o Tribunal de Justiça de São Paulo, que tem afastado o caráter de intransmissibilidade e incluído o quantum apurado a esse título entre os bens a inventariar e, consequentemente, a partilhar entre os herdeiros; ora por entender possuir caráter de mero ativo financeiro, ora por equiparar a investimento financeiro. Nesse diapasão, podem ser mencionados os seguintes julgados da Corte paulista:

\begin{abstract}
Agravo de Instrumento. Inventário. Valores aplicados em fundos de previdência privada. I- Fundos de previdência privada. Ausência de feição securitária a franquear a aplicação do disposto no art. 794 do CC. Inexistência de risco que empresta lastro aos contratos de seguro. Doutrina. II- Valores depositados em Fundos de Previdência Privada que exibem feição de aplicação financeira. Inteligência do artigo 202, EC 20, de 15.12.98. Sujeição desses valores à colação no inventário. Precedentes desta Câmara (Ap.1015490-23.2014.8.26.0562, Rel. Viviani Nicolau, Ap. 0022280-94.2012.8.26.0014, Rel. Donegá Morandini e deste Tribual (Ap.543.262-4/5-00, 4ª . Câmara de Direito Privado, Rel. Natan Zelinschi de Arruda. Decisão reformada. Agravo provido. (TJSP. $3^{a}$. Câmara de Direito Privado. Agr. n. ${ }^{\circ}$ 2163200-96.2016.8.26.0000, rel. Des. Donegá Morandini, v. u., j. em 13.12.2016).

Agravo de Instrumento. Inventário. Pretensão de bloqueio de depósitos mantidos pelo espólio inventariado em conta de PGBL. Deferimento Necessário. Relevante controvérsia acerca da natureza dos montantes e da disponibilidade de meação pelo espólio agravante, influindo diretamente no direito dos sucessores. Vultosa quantia monetária que evidencia, no mais, dano de difícil reparação diante da possibilidade de saque administrativo junto à instituição financeira. Impedimento de levantamento de valores até que se confira solução sobre a natureza dos direitos tratados. Provimento que deflui do poder geral de cautela do magistrado. Inteligência do artigo 297, CPC/15. Decisão reformada.

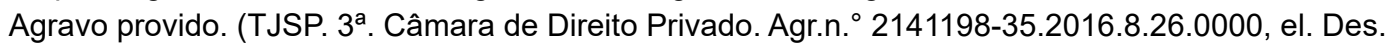
Donegá Morandini, v. u., j. em 18.10.2016).
\end{abstract}

Como ensina, entretanto, Carvalho (2004, p. 127), "o plano previdenciário é tipo especial de seguro, o que se confirma pela decisão do STF no RE n. ${ }^{\circ} 115.308-3 / R J$, razão pela qual incide o disposto no art. 777 do CC/2002, o qual prevê que o disposto naquele capítulo (pertinente a seguro) somente é aplicável no que couber ao seguro regido por lei própria". 
Os julgados do Tribunal de Justiça de São Paulo negaram vigência ao art. 794 CC02, bem como não aplicaram as regras da Lei Complementa n. ${ }^{\circ} 109 / 01$, as quais regem a formação das reservas dos planos de previdência privada e Ihes fixa a natureza. Cumpre, também, destacar que o fato de se revelar como bom investimento financeiro não desnatura a sua natureza securitária, tampouco as finalidades para as quais são legalmente direcionados os fundos de previdência privada, ainda porque a causa não é elemento do negócio jurídico.

\title{
6. 2 Incidência de ITCMD
}

Outro ponto passível de questionamento é a não incidência do ITCMD. Algumas leis estaduais preveem sua incidência, como a Lei n. ${ }^{0} 18.573 / 15$ do estado do Paraná. Em sentido contrário, a Fazenda estadual paulista, em resposta à Consulta Tributária n. ${ }^{\circ}$ 79/12, reconheceu a não incidência do tributo: "Não incidência de ITCMD sobre valores recebidos a título de benefício da Previdência Complementar em razão de ter mesma natureza de seguro de vida."

O Tribunal de Justiça de Minas Gerais já reconheceu não incidir o ITCMD nas reservas constituídas nos planos de previdência privada, como demonstra o presente julgado:

\begin{abstract}
EMENTA: APELAÇÃO CÍVEL - AÇÃO DE REPETIÇÃO DE INDÉBITO TRIBUTÁRIO - ITCMD INCIDÊNCIA SOBRE SALDO DE PLANO VGBL - IMPOSSIBILIDADE - NATUREZA DE CONTRATO DE SEGURO DE PESSOAS - APLICAÇÃO DO ART. 794 DO CC/02 - PROGRESSIVIDADE DE ALÍQUOTAS - ART. 10 DA LEI ESTADUAL 14.941/03 (REDAÇÃO ORIGINAL) -- INCONSTITUCIONALIDADE - CORREÇÃO MONETÁRIA E JUROS MORATÓRIOS - INAPLICABILIDADE DA LEI 11.960/09 - RECURSO NÃO PROVIDO. 1) O VGBL (Vida Gerador de Benefícios Livres) é um plano por sobrevivência classificado como seguro de pessoas, aplicando-se, por força do art. 73 da LC 109/2001, o disposto no artigo 794 do Código Civil de 2002, que o descaracteriza como herança para todos os fins de direito, impedindo que a sua inclusão em inventário e tributação pelo ITCMD. 2) A progressividade de alíquotas do ITCMD prevista no art. 10 da Lei Estadual 14.941/02 (redação original) é inconstitucional, por desconsiderar a capacidade econômica real do contribuinte. 3) Diante da ilegalidade da alíquota de $6 \%$ aplicada pelo Fisco (inciso I, alínea 'd') e, por não ser possível aplicar a alíquota mínima de 3\% (aliena 'a') ao caso concreto, sob pena de 'reformatio in pejus', deve ser mantido o percentual pleiteado pelos autores e adotado pelo sentenciante: $5 \%$ (alínea 'c'). 3 ) Cuidando-se de repetição de indébito tributário, incidem juros moratórios no importe de $1 \%$ ao mês, desde o trânsito em julgado, na forma do artigo $161, \S 1^{\circ}$ do CTN, sendo inaplicável a Lei n. 11.960/09, incidindo-se correção monetária pela tabela da Corregedoria-Geral de Justiça desde o pagamento indevido. (TJMG - Apelação Cível 1.0145.08.478656-8/001, relator(a): Des. ${ }^{a}$ Teresa Cristina da Cunha Peixoto, $8^{a}$ CÂMARA CíVEL, julgamento em 31/01/2013, publicação da súmula em 14/02/2013).
\end{abstract}

O Tribunal de Justiça do Rio de Janeiro compartilha o mesmo entendimento. ${ }^{8}$ Há divergência entre os articulistas. Dayana Uhdre entende não serem tributáveis pelo ITCMD os valores do VGBL, mas que seriam os do PGBL. Afirma:

De qualquer forma, ancorando-nos nos dispositivos constitucionais, legais e infralegais regentes do assunto, é possível concluir que o plano PGBL é apenas modalidade de benefício previdenciário, não detendo natureza securitária, o que justifica, nesse caso, a eventual incidência de ITCMD. Já o VGBL é considerado seguro com cobertura por sobrevivência, o que estaria fora do âmbito de incidência do referido tributo estadual (art. 110 do CTN (LGL/1966/26) c/c 794 do CC). (UHDRE, 2017, p. 128).

Não obstante a opinião da articulista, algumas considerações hão de ser feitas, que infirmam sua conclusão.

\footnotetext{
"Agravo de Instrumento. Anulatória de lançamento fiscal. Inventário extrajudicial. Recolhimento do ITCMD sobre o saldo da previdência privada na modalidade VGBL. Decisão antecipando os efeitos da tutela pleiteada, suspendendo a exigibilidade do crédito tributário. Inconformismo ventilado pela fazenda estadual. - Entendimento de que o saldo de plano de previdência privada na modalidade VGBL é um produto securitário, e, por tal razão, não é considerado herança consoante dispõe a regra prevista no art. 794 do Código Civil (LGL/2002/400). Recurso desprovido." ( TJRJ - Al 003797617-2015.8.19.0000 Rio de Janeiro Capital 11․ Vara Faz. Pública, Rel. Desa. Flávia Romano de Rezende, j. em 02.12.15, 17a. Câmara Cível, DJ 03.12.2015.) No mesmo sentido, outras decisões proferidas no TJRJ: Al 003572356-20.2015.8.19.0000 Rio de Janeiro Niterói 7. ${ }^{\text {a }}$ Vara Cível Pública, rel. des. Juarez Fernandes Folhes, j. em 27.01.2016, 14. ${ }^{a}$ Câmara Cível, DJ 29.01.2016, e Al 0062338-20.2014.8.19.0000, rel. des.

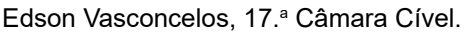


Em primeiro lugar, não se pode desconsiderar a natureza contratual dos fundos de previdência privada, bem como a presença de características que the assemelham ao contrato de seguro de pessoas, apesar de possuírem características peculiares e próprias. A instituição de previdência privada administra o patrimônio do interessado de acordo com os limites e termos do contrato pactuado, nos moldes assemelhados aos contratos de seguro em geral.

A finalidade da contratação é a formação de reserva para obtenção de renda complementar previdenciária, de modo a se obter proteção contra riscos cobertos por meio de prestações econômicas, característica também presente em outras modalidades de seguro de pessoa. Saliente-se ser indiscutível sua natureza contratual, tendo, inclusive o STJ, ao editar a Súmula n. ${ }^{\circ} 321$, consagrado a incidência do Código de Defesa do Consumidor à relação jurídica estabelecida entre a entidade de previdência privada e seus participantes. ${ }^{9}$

O site da Superintendência de Seguros Privados (Susep) informa que os planos previdenciários podem oferecer os seguintes benefícios: i) renda por sobrevivência; ii) renda por invalidez; iii) pensão por morte; iv) pecúlio por morte; v) pecúlio por invalidez. Referidos benefícios também são passíveis de ser obtidos por meio de contratos de seguro de outras modalidades.

Em segundo, com a morte do titular, a reserva acumulada a título de PGBLé destinada aos beneficiários indicados na apólice contratada, os quais podem ser pessoas alheias à família de seu titular, não estando presente caráter previdenciário nessa destinação. Trata-se de estipulação em favor de terceiros, figura jurídica prevista no art. 436 CC02.

Em terceiro, o VGBL e o PGBL possuem o mesmo fundamento constitucional e legal, ou seja, a mesma matriz normativa, não existindo dispositivo legal que permita concluir apresentar o PGBL natureza distinta do VGBL. Pelo contrário, há regras comuns previstas para ambos pela Lei Complementar $\mathrm{n} .^{\circ} 109 / 01$, e as Resoluções n. ${ }^{\circ} 139$ e 140 reforçam, como já mencionado, a natureza securitária de ambos. Essa posição é compartilhada por Ricardo Bechara Santos (2015, p. 116):

Assim é que, qualquer seguro de vida, seja constituído sob o regime de repartição simples, seja sob o regime de acumulação ou capitalização, é absolutamente impenhorável por força de norma legal expressa, assim como os planos de previdência privada, inclusive o PGBL, quanto mais os planos tradicionais, por sua inegável identidade com o seguro de vida. Não sem lembrar que, em face do artigo 73 da LC 109/01, as entidades de previdência privada complementar, serão reguladas também, no que couber pela legislação aplicável às sociedades seguradoras, havendo, portanto, certa intenção do legislador de aproximar o contrato de seguro do contrato de previdência privada.

\section{3 Alegação de violação da legítima}

Caso não apresentasse natureza securitária e, portanto, fosse reconhecida sua natureza de patrimônio transmissível mortis causa, os fundos depositados nos planos (VGBL e PGBL) seriam transmissíveis aos sucessores, pois comporiam o monte da herança a partilhar.

Assim, na hipótese de existirem herdeiros legítimos necessários, as reservas constituídas deveriam ser consideradas para fins de cálculo do patrimônio disponível, compreendido como o patrimônio passível de ser livremente disposto por seu titular por meio de testamento, e da legítima, porção da herança obrigatoriamente destinada aos herdeiros legítimos necessários, ex vi do art. 1.846 CC02. Do mesmo modo, estaria configurado o dever de colacionar os valores recebidos a esse título, em conformidade com $\mathrm{o}$ art. $2.002 \mathrm{CC} 02$.

A legítima é instituto que tem sua origem no direito pretoriano em Roma, e visava à tutela dos interesses hereditários de descendentes e ascendentes. O art. $1.845 \mathrm{CC} 02$ inseriu entre os herdeiros legítimos necessários o cônjuge. Hoje, considerando as múltiplas estruturas apresentadas pela família em nossa sociedade, o papel da legítima deveria ser revisto, modificando-se de modo a possibilitar maior liberdade no ato de disposição do patrimônio mortis causa.

9 Vide a próposito Bruno Miragem (2011). 
O fato de serem os fundos de previdência privada excluídos da herança pode, eventualmente, gerar situação em que um dos herdeiros legítimos necessários seja mais beneficiado do que outro. Desse modo, estaria comprometida a igualdade entre os herdeiros legítimos necessários e o cumprimento da legítima. Não se pode afastar a possibilidade dessa ocorrência, ou mesmo sua utilização com fins fraudatórios.

Mauro Fitermann (2015, p. 106-107) entende que, nessa situação, estaria sendo violado o princípio da boa-fé objetiva, bem como caracterizado abuso de direito, nos ditames do art. 187 CC02. Assevera:

\begin{abstract}
A princípio, então, se um indivíduo, em vida, aportar valores em contratos de previdência privada, esses valores, no futuro, quando de sua morte, não integrarão a sua herança. Entretanto, esses complexos contratos de previdência privada têm-se caracterizado, a cada novo momento, como multifacetários. Essas facetas todas acabam por retirar desses contratos a essência daquilo que os afastou da condição herança, com base em um exame do conteúdo material do tema, podendo, por vezes, servir à violação dos direitos decorrentes da necessariedade como princípio, violando o instituto da colação.
\end{abstract}

Observe-se que, pela análise formal do tema, um indivíduo poderia transferir valor superior à metade de seus bens, indicando como beneficiário desse valor um dos seus herdeiros necessários ou até mesmo terceiros. Por se tratar de uma previdência privada, esse valor recebido pelo herdeiro não estaria sujeito à colação.

Evidente que tal postura rompe com a finalidade do instituto da colação antes explicitada, uma vez que, notadamente, a postura estaria violando a boa fé objetiva como princípio, consagrando-se $o$ abuso do direito nos termos do disposto no art. 187 do CC02.

Conclui o articulista que, nessas situações, as reservas constitutivas dos fundos de previdência deveriam ser incluídas no montante a partilhar, respeitando-se a legítima e preservando-se o direito dos herdeiros legítimos necessários.

Essa questão é também abordada por Eduardo Rocha Dias (2014, p. 131), para quem "a princípio, deve prevalecer a liberdade de indicação. No entanto, se for comprovado que o valor aportado supera metade do patrimônio do participante, aí sim caberá invocar a previsão do mencionado dispositivo, e buscar limitar o valor a ser destinado à pessoa indicada."

A resposta à situação dependerá, no entanto, de se estar diante de situação de normalidade ou de situação excepcional, provocada por má-fé e com nítido intuído de fraudar a lei.

A Constituição Federal consagra como direito fundamental o direito de propriedade. $O$ direito de disposição compõe o conteúdo do direito de propriedade. O titular do patrimônio tem legitimidade e pode validamente celebrar negócios jurídicos onerosos dispondo dos bens componentes do seu patrimônio, assumindo obrigações e direitos.

Pode, também, praticar atos gratuitos de transferência patrimonial, por exemplo, a doação aos pais, aos filhos e ao cônjuge, ou mesmo a terceiros. Nas hipóteses de doações de bens a filhos e cônjuges, estes, quando da abertura da sucessão mortis causa, têm o dever de trazer à colação os bens recebidos em vida do de cujus, de acordo com os artigos 544 e 2002 do CC02. A legítima de cada herdeiro necessário é determinada após o pagamento dos débitos e obrigações de titularidade do falecido, bem como das despesas do sepultamento. Ao saldo obtido são acrescidos os bens trazidos à colação, determinando-se, então, o quinhão de cada herdeiro. A finalidade é propiciar a igualdade entre as legítimas dos herdeiros legítimos necessários chamados à sucessão, nos termos do art. 2003 do CC02. Portanto, o universo da herança a partilhar é determinado somente após a abertura da sucessão, que ocorre com a morte do titular do patrimônio.

Os ascendentes donatários, bem como os terceiros, não têm o dever de colacionar. No entanto, se a doação tiver ultrapassado a parte disponível (cinquenta por cento) do patrimônio do doador, estará sujeita à redução por inoficiosidade, ex vi do art. 2007 CC02, até chegar ao limite do disponível, pois apenas o que exceder à legítima é considerado nulo, de acordo com a precisa dicção do art. 549 CC02.

A prática de negócios jurídicos onerosos e de natureza comutativa não se sujeita às restrições da legítima, porque não acarreta redução patrimonial, ainda que, considerando os riscos inerentes à atividade 
negocial, possam se revelar prejudiciais. Nada obsta, portanto, que o titular do patrimônio transforme bens imóveis ou móveis em valores mobiliários.

O negócio jurídico realizado com a finalidade de constituir reserva destinada à formação de fundo de previdência privada caracteriza-se como negócio de longo prazo e de execução continuada. Inicia-se com depósito inicial, cujo valor é determinado pelo interessado, e prossegue com o depósito de valores mensais, sendo possível o aporte de valores extras a qualquer tempo. Constituem patrimônio por afetação, pois destinado à finalidade específica.

Em situações normais, e quando houver prévia indicação dos beneficiários, os valores constitutivos das reservas de previdência privada não se sujeitam à partilha por não integrarem a herança, como já destacado. Isso ocorre mesmo que a reserva constituída seja maior do que a porção disponível, apurada quando da abertura da sucessão, pois os dois montantes patrimoniais apresentam naturezas jurídicas distintas e a reserva constituída apresenta a natureza jurídica de patrimônio por afetação.

À reserva constitutiva dos fundos de previdência privada aplica-se o regime jurídico próprio dos capitais de natureza securitária, incluindo-se o disposto pelo art. 794, que o exclui, expressamente, da herança. Por esse motivo, é irrelevante, para determinar a obrigatória observação da legítima, o fato de, eventualmente, os montantes depositados a título de PGBL ou VGBL serem superiores à parte disponível da herança.

A solução, no entanto, pode ser outra se demonstrado que a celebração dos negócios jurídicos de constituição dos fundos de previdência privada (PGBL ou VGBL) ocorreu com o nítido intuito de fraudar a legítima dos herdeiros legítimos necessários ou mesmo os credores do falecido. Na primeira hipótese, estaria configurada situação de fraude à lei, ou mesmo de abuso de direito, nos termos do artigo 187 CC02, como aponta Fiterman (2015). Na segunda, poderia se caracterizar, a depender da situação concreta, fraude contra credores ou fraude à execução. Em ambos os casos, ressalte-se, é indispensável uma prova da má-fé do falecido, caracterizada pela consciente intenção de lesar os herdeiros legítimos necessários ou os credores.

Nessas situações excepcionais, os prejudicados, herdeiros legítimos necessários, poderiam pleitear a incorporação das reservas dos fundos de previdência privada (PGBL ou VGBL) no montante a partilhar da herança; e os credores, a constrição dos valores para pagamento dos débitos do falecido.

A incorporação dos valores à herança exige decisão do juízo da sucessão nesse sentido, sendo sua partilha processada segundo as regras da sucessão legitima ou do testamento, se for o caso.

\section{4 Taxas de administração}

As taxas de administração cobradas pelas instituições de previdência privada podem comprometer a eficácia dos fundos de previdência como investimento financeiro. Porém, à medida que o valor dos recursos aplicados aumenta, decresce a taxa de administração, assim como a alíquota do imposto de renda incidente. As taxas de administração, todavia, não comprometem a utilização dos fundos de previdência privada como instrumentos de planejamento sucessório, sendo comuns nos investimentos financeiros e mobiliários em geral.

\section{5 Solvência da instituição financeira e administração dos fundos de previdência}

Trata-se de risco de caráter genérico, presente em virtude, muitas vezes, do comprometimento da saúde financeira das instituições de previdência privada. Por essa razão, deve-se investigar a solidez financeira da instituição com a qual se pretende contratar, principalmente por se tratar de contrato de longo prazo. Os contratos de previdência privada são contratos que dependem da boa gestão dos recursos financeiros acumulados nos fundos, cujo equilíbrio econômico financeiro deve ser resguardado.

Dessa forma, é importante investigar a prática de gestão por parte das instituições de previdência privada, pois os jornais noticiam, com relativa frequência, o cometimento de atos de gestão temerária e de má gestão administrativa dos fundos previdenciários, comprometendo não somente sua solvabilidade, como também o futuro dos poupadores. 


\section{Conclusão}

A utilização da previdência privada como meio de planejamento sucessório é compatível com sua natureza e seu regime jurídico, apesar de desbordar dos objetivos com que foi prevista normativamente. Consiste, na verdade, em saída desenvolvida pelos aplicadores do direito, em particular advogados e administradores financeiros, para viabilizar o atendimento das necessidades do titular do patrimônio quanto ao modo de destinação de seu patrimônio mortis causa, em função, particularmente, da desconformidade das regras de sucessão legítima com as estruturas familiares contemporâneas.

Viabiliza, ainda, benefícios de natureza tributária, pois não enseja a incidência do ITCMD, bem como possibilita a dedução das contribuições da base de cálculo do IRPF.

A exclusão dos valores depositados em previdência privada da herança, em virtude da natureza securitária que a lei lhe atribui, propicia rapidez em sua destinação aos beneficiários indicados pelo titular do patrimônio, ou aos herdeiros legítimos, se não houver nomeação de beneficiários. Por não serem incluídos na herança, os referidos valores não respondem pelos débitos do de cujus ou da herança, ressalvada a situação em que caracterizada má-fé, fraude a lei ou fraude contra credores, hipóteses em que a lei enseja a ineficácia ou invalidade do negócio jurídico, conforme o caso.

Apesar de sua aptidão como instrumento de planejamento sucessório, sua aplicação com esse escopo é questionada tanto pela Doutrina como pelos Tribunais.

A principal causa desse questionamento reside na possibilidade de sua indevida utilização como meio de fraudar a legítima, prejudicando os herdeiros legítimos necessários, seja por meio da designação de terceiros como beneficiários, seja por meio da distribuição desigual dos quinhões hereditários.

Com efeito, a realização de negócio jurídico objetivando a constituição de reserva em fundo de previdência privada aberta pode ser analisada tanto sob a ótica objetiva como subjetiva dos elementos do fenômeno sucessório.

Caracterizada a má-fé ou o abuso de direito na utilização da previdência privada como meio de burlar a legítima dos herdeiros necessários, os referidos valores devem ser incorporados à herança e partilhados entre os herdeiros legítimos, testamentários e legatários, de acordo com as regras da sucessão legítima, ou com as fixadas no testamento, respectivamente.

Assim, ultrapassado o montante da parte disponível, deve-se proceder à redução por inoficiosidade, de acordo com o previsto no art. 2.007 CC02, ou seja, as disposições previstas no título de previdência privada hão de ser diminuídas, de modo a observar o percentual de $50 \%$ da parte disponível, à semelhança do que ocorreria se tivessem sido veiculadas por meio de testamento.

Quanto ao aspecto subjetivo, há, ainda, a possibilidade de ser caracterizada fraude à lei se houver a designação como beneficiária de pessoa que não tenha legitimidade para suceder, nos termos do art. 1.802 CC02. Note-se, prevê o art. 1.802, § único, a nulidade da disposição que beneficiar quaisquer das pessoas não legitimadas a concorrer, mesmo que instrumentalizada por meio de contrato oneroso, ou se fizer uso de interposta pessoa. Na hipótese, incide o disposto no art. 166, VII, CC02, que prevê a nulidade do negócio jurídico.

Ressalvadas as situações acima referidas, para as quais o ordenamento jurídico fornece soluções próprias, a natureza jurídica da previdência privada complementar permite sua utilização como instrumento útil e eficaz de planejamento sucessório.

\section{Referências}

AMARAL FILHO, Léo do. Previdência privada aberta. São Paulo: Quartier Latin do Brasil, 2005. ARAÚJO NETO, Raul Lopes de. Tributação e previdência complementar. Rio de Janeiro: Lumen Juris, 2013. 
CARVALHO, Rodrigo José de Kuhl. As entidades abertas de previdência complementar sem fins lucrativos e o novo código civil. Revista dos Tribunais, São Paulo, v. 93, n. 830, p. 77-129, dez. 2004.

FITERMAN, Mauro. Os complexos contratos de previdência privada e a colação. Revista dos Tribunais, São Paulo, v. 104, n. 953, p. 101-110, mar. 2015.

GONÇALVES, Antônio Baptista. PGBL X VGBL: a realidade tributária para o investidor financeiro.

Revista Tributária e de Finanças Públicas, São Paulo, v. 68, maio/jun. 2006.

MIRAGEM, Bruno. Os contratos de previdência privada e o código de defesa do consumidor na visão do Superior Tribunal de Justiça: comentários sobre as súmulas 289, 291, 321 e 427 do STJ. Revista de Direito do Consumidor, São Paulo, v. 21, n. 85, abr./jun. 2011.

ROCHA DIAS, Eduardo. Liberdade de indicação dos beneficiários nos planos de previdência privada: um diálogo entre a Constituição, o Código Civil e a legislação previdenciária. Revista dos Tribunais, São Paulo, v. 948, p. 117-134, 2014.

SANTOS, Ricardo Bechara. Impenhorabilidade de ativos: seguros e previdências. Revista Jurídica de Seguros da CNSEG, Rio de Janeiro, n. 3, p. 77-116, 2015.

SOLLEDERO FILHO, José. O direito do seguro no Brasil e na França: estudo comparativo em seguros de danos e de pessoas. In: FÓRUM DE DIREITO DO SEGURO, 3, 2003, São Paulo. Anais [...]. São Paulo: Instituto Brasileiro de Direito do Seguro, 2003.

UHDRE, Dayana. Sobre a incidência de ITCMD sobre os planos PGBL e VGBL de previdência complementar: algumas distinções necessárias. Revista de Direito Tributário Contemporâneo, Brasília, v. 2, n. 8, p. 117-134, set./out. 2017.

WEINTRAUB, Arhtur Bragança de Vasconcellos. Previdência privada: doutrina e jurisprudência. São Paulo: Quartier Latin do Brasil, 2005.

Recebido em: 03/06/2019

Aprovado em: 22/08/2019 